\title{
Color Changes of Polyamid and Polymetyhl Methacrylate Denture Base Materials
}

\author{
Nurdan Polat Sagsoz, Nuran Yanıkoglu*, Hamza Ulu, Funda Bayındır \\ Prosthodontics Department, School of Dentistry, Ataturk University, Erzurum, Turkey \\ Email: nurdansagsoz@hotmail.com, ․ㅡyanikoglu@yahoo.com, hamza.ulu@atauni.edu.tr, \\ fundabayindir@gmail.com
}

Received 23 August 2014; revised 7 October 2014; accepted 23 October 2014

Copyright (C) 2014 by authors and Scientific Research Publishing Inc.

This work is licensed under the Creative Commons Attribution International License (CC BY).

http://creativecommons.org/licenses/by/4.0/

(c) (i) Open Access

\begin{abstract}
Aim: Both conventional and flexible resins may show color alteration due to intrinsic and extrinsic factors. The aim of this study was to evaluate the color changes of the polyamid and heat polymerized acrylic denture base materials in storage of different staining solutions. Methods: Two denture base materials were used in this study. The speciemens were stored in two staining solutions (tea, coffee), distilled water and denture cleaner. For each group, 14 speciemens $(25 \times 15 \times 2.5$ $\mathrm{mm}$ ) were prepared. The color of speciemens was measured using a colorimeter according to the CIE $\mathrm{L}^{*} \mathrm{a}^{*} \mathrm{~b}^{*}$ color scale. The color changes of speciemens were evaluated before and after 7 and 30 days. All data recorded were taken by the same investigator to minimize inconstancy of technique. The data were analyzed statistically by repeated measures analysis of variance and Tukey honestly significant difference multiple comparison tests. It was found no statistically significant difference between solutions ( $P$ > 0.05). Results: Polyamid denture base resin displayed the greatest colour change when compared to polymetyhl methacrylate denture base resin $(P<0.001)$. Polyamid material indicated the highest value $(\Delta E: 7.28)$ in coffee solution for 7 days. Significance: The colour stability of polymetyhl methacrylate denture base resin is greater than polyamid denture base resin.
\end{abstract}

\section{Keywords}

Color Stability, Polyamid, Polymetyl Methacrylate, Denture Base, Solution

\section{Introduction}

Most dental patients of all ages prefer to avoid the use of metal in dental treatment because of their desire for a bright, white smile. Due to such increased esthetic expectations, thermoplastic resins have recently become a treatment option for patients [1]. Some potential alternative materials to polymetilmethacrilat (PMMA) used in

\footnotetext{
${ }^{*}$ Corresponding author.

How to cite this paper: Sagsoz, N.P., Yanıkoglu, N., Ulu, H. and Bayındır, F. (2014) Color Changes of Polyamid and Polymetyhl Methacrylate Denture Base Materials. Open Journal of Stomatology, 4, 489-496. 
such cases are such as polycarbonate and nylon [2]. Nylon is a generic name for certain types of thermo-plastic polymers belonging to the class known as polyamides. These polyamides are produced by the condensation reactions between a diamine and a dibasic acid [3]. Flexible resins have some advantages: superior esthetics, reduced potential reactions to metal, flexibility and highly elastic nature [4]. These are translucency, a natural appearance without laboratorial characterization; they prevent prosthesis fractures, allow lighter and more comfortable prothesis. Besides, flexible resins require no tooth preparation as conventional RPDs do and they reduce the chair time [5] [6]. Nylon denture base material could be a useful alternative to poly (methyl methacrylate) (PMMA) in special circumstances such as patient allergy to the monomer [3].

Plymethyl methacrylate resin has been used for a long time as the best choice to fabricate full or partial dentures because of its esthetic qualities and ease of maniplation. Nevertheless, their mechanical properties should be improved [7].

Color stability of denture base acrylic resins is a concern, as it is associated with esthetic reproduction of oral mucosa. For this reason, colorants and other constituents of denture base resins should be stable during denture fabrication [8]. Discoloration of acrylic resins may be caused by several factors. Intrinsic factors such as degree of conversion and residual monomer can influence color stability. Another possible source of color change is the porosity. It is caused by overheating or pressure during processing [9]. Color stability of denture base resins is associated with eating habits. It has been reported that certain beverages, such as tea, coffee, and wine, cause discoloration of acrylic resins [10]. Some of the extrinsic factors are: the effect of cleaning solutions, tobacco, composition of saliva and denture hygiene habits [11].

The discoloration of resin restorations can result in an esthetic problem. Minimizing color change is a factor that should be used in the selection of materials and techniques for the best esthetic effect; the material should be translucent. Color and translucency should be maintained during processing and these resins should not get stained or changed in clinic use. The color stability criteria may provide important information on the servicability of materials [12].

The aim of this study was to evaluate the effect of different staining solutions and times of storage on the color stability of the polyamid and polymetyhl methacrylate denture base materials.

\section{Materials and Method}

Two denture base materials were used in this study: heat-polymerized polymethylmethacrylate (Meliodent, Bayer Co. Germany) and polyamid (Deflex ${ }^{\circledR}$, Nuxen S.R.L., Buenos Aires, Arjantin) denture materials. Polyamid is a thermo-injectable resin, which belongs to the polymer series.

Polyamid is made liquid by heating with Micro Injection Molding Machine automatically and injected with pressure to the prothesis molds.

For each group, 14 speciemens $(25 \times 15 \times 2.5 \mathrm{~mm})$ were prepared. These speciemens were wet-polished with up to 1200 grit abrasive paper. After immersion in distilled water at $37^{\circ} \mathrm{C}$ for 48 hours, the speciemens were dried.

\subsection{Preparation of Staining Solutions}

Two staining solutions (tea, coffee), distilled water and denture cleanser were used in this study. To prepare the coffee solution, $3 \mathrm{~g}$ of coffee (Kahvecizade Mehmet Efendi; Y. Dudullu, Istanbul, Turkey) was added into 150 $\mathrm{mL}$ of boiling water. The tea solution was prepared by immersing two tea bags that each contained $2 \mathrm{~g}$ of tea (Lipton Yellow Label Tea; Unilever, Istanbul, Turkey) into $150 \mathrm{~mL}$ of boiling water for $10 \mathrm{~min}$. The coffee and tea solutions were then stirred for 10 severy 15 min until the temperature of the solution was $37^{\circ} \mathrm{C}$, and then passed through filter paper to remove any particulate residues. The denture cleanser solution was prepared by added one denture cleanser (Corega Tabs, Stafford-Miller Ind., Rio de Janeiro, RJ, Brazilin) to $150 \mathrm{ml}$ of boiling water. Each solution was stirred once a day in order to reduce the precipitation of particles, and replaced daily.

\subsection{Colour Measurements}

Color measurements were performed for each speciemen before and after soaking, using the CIE $\mathrm{L}^{*} \mathrm{a} * \mathrm{~b} *$ color space system [13]. The measurements of color changes of the speciemens were made randomly selected area the center of each specimen. The color changes of speciemens were evaluated before and after 7 and 30 days of im- 
mersion in different solutios (tea, coffee and denture cleaner) and distilled water. For these repeated colour measurements, each speciemens was rinsed in water for $5 \mathrm{~min}$, and then blotted dry with tissue paper before the color measurement. After desiccation, the color of speciemens was measured using a colorimeter (Shade Eye NCC; Shofu Dental Corporation, Kyoto, Japan). Before each measurement the colourimeter was calibrated according to the manufacturer's recommendations. All data recording were taken by the same investigator to minimize inconstancy of technique.

In addition, the differences in the $\mathrm{L}^{*} \mathrm{a} \mathrm{b}^{*}$ values of the five specimens in each group before and after soaking were compared using acrylic resin as a control group.

The color differences resulting from soaking were calculated using the following equation [14].

$\Delta \mathrm{E}^{*} \mathrm{ab}=\left\{\left(\Delta \mathrm{L}^{*}\right) 2+\left(\Delta \mathrm{a}^{*}\right) 2+\left(\Delta \mathrm{b}^{*}\right) 2\right\} 1 / 2$

$\Delta \mathrm{L}^{*}=\mathrm{L}^{*} \mathrm{O}-\mathrm{L}^{*} \mathrm{t}$

$\Delta \mathrm{a}^{*}=\mathrm{a}^{*} \mathrm{O}-\mathrm{a} * \mathrm{t}$

$\Delta \mathrm{b}^{*}=\mathrm{b}^{*} \mathrm{o}-\mathrm{b}^{* \mathrm{t}}$

$\mathrm{L} * \mathrm{t}, \mathrm{a} * \mathrm{t}, \mathrm{b} * \mathrm{t}$ : before soaking

$\mathrm{L}^{*} \mathrm{o}, \mathrm{a}^{*} \mathrm{o}, \mathrm{b}{ }^{*} \mathrm{o}$ : after soaking

$\Delta \mathrm{E}$ value of 3.7 or less is considered to be hardly visible also clinically acceptance. In order to relate $\Delta \mathrm{E}^{*}$ to the clinical environment; the values of color changes converted to National Bureau of Standard units showed them to be perceivable to the human eye.

NBS units $=\Delta \mathrm{E}^{*} \times 0.92$ where the specific colour differences are expressed in terms of NBS units.

\subsection{Statistical Analysis}

The data were analysed statistically by repeated measures analysis of variance (ANOVA), one- and two-way ANOVA, and Tukey honestly significant difference (HSD) multiple comparison tests.

\section{Results}

The minimum, maximum, means and Standard deviations values for all materials after stored in the staining solutions are shown in Table 1.

Repeated measures analysis of variance (ANOVA) showed that there was a significant differences between denture base materials $(\mathrm{P}<0.001)$. But, it was found no statistically significant differences between solutions in PMMA for 7 days and polyamid material for 30 days $(\mathrm{P}>0.05)$.

The colour changes of polyamid denture base resins are greater than polymetyhl methacrylate denture base resins. The highest coloration values were shown in polyamid material in stored coffee.

The colour differences of PMMA and polyamid base materials after their immersion in the four solutions for 7 and 30 days are summarised in Figure 1 and Figure 2.

There was a statistically significant differences between solutions for PMMA in stored 30 days $(\mathrm{P}<0.05)$, the highest mean value $(\Delta \mathrm{E}>3.7)$ was found in tea for 30 days.

There was a statistically significant differences between solutions for polyamid material $(\mathrm{P}<0.05)$ in stored seven days, the highest mean value $(\Delta \mathrm{E}>3.7)$ was found in stored coffee solution for 7 days.

\section{Discussion}

An increased awareness of esthetics in dentistry has led to the need of removable partial dentures (RPDs) that reveal little or none of the metal supporting structures or retentive elements [15]. The indication of more esthetic materials without metallic support such as flexible resins is limited due to the lack of information provided by manufacturers or literature regarding alterations in chromatic stability and microhardness.

Both conventional and flexible resins suffered color alteration following aging due to intrinsic and extrinsic factors. Intrinsic factors involve the discoloration of the resin material itself, such as the alteration of the resin matrix and interface of matrix and fillers [16].

Intrinsic factors include discoloration of material, with alteration of the matrix. Extrinsic factors such as absorbtion and adsorption of substances in conventional resins may also lead to discoloration [16]-[18].

In the present study was evaluated the color changes of the polyamid and heat polymerized acrylic denture base materials in storage different staining solutions. The colour stability of PMMA material is greater than 
Table 1. The minimum, maximum, means and standard deviations values for all materials.

\begin{tabular}{|c|c|c|c|c|c|c|}
\hline Immersion time & Material & Solution & Minimum & Maximum & Mean & SD \\
\hline \multirow{8}{*}{ Seven days } & \multirow{4}{*}{ Polyamid } & Distilled water & 0.91 & 10.15 & 3.85 & 2.44 \\
\hline & & Tea & 2.78 & 10.13 & 4.61 & 2.00 \\
\hline & & Denture cleanser & 0.87 & 9.59 & 4.82 & 2.53 \\
\hline & & Coffee & 3.20 & 12.78 & 7.28 & 3.00 \\
\hline & \multirow{4}{*}{ Pmma } & Distilled water & 0.70 & 4.50 & 2.52 & 1.33 \\
\hline & & Tea & 1.82 & 4.20 & 2.56 & 0.69 \\
\hline & & Denture cleanser & 0.73 & 4.39 & 2.24 & 1.08 \\
\hline & & Coffee & 0.79 & 4.08 & 2.45 & 0.94 \\
\hline \multirow{8}{*}{ Thirty days } & \multirow{4}{*}{ Polyamid } & Distilled water & 1.55 & 14.83 & 6.21 & 3.71 \\
\hline & & Tea & 3.45 & 8.57 & 5.88 & 1.61 \\
\hline & & Denture cleanser & 0.81 & 9.88 & 5.97 & 2.57 \\
\hline & & Coffee & 5.08 & 10.30 & 6.59 & 1.63 \\
\hline & \multirow{4}{*}{ Pmma } & Distilled water & 0.83 & 4.53 & 2.40 & 1.17 \\
\hline & & Tea & 2.26 & 7.16 & 4.20 & 1.30 \\
\hline & & Denture cleanser & 1.62 & 6.30 & 3.24 & 1.25 \\
\hline & & Coffee & 1.64 & 4.22 & 2.81 & 0.83 \\
\hline
\end{tabular}

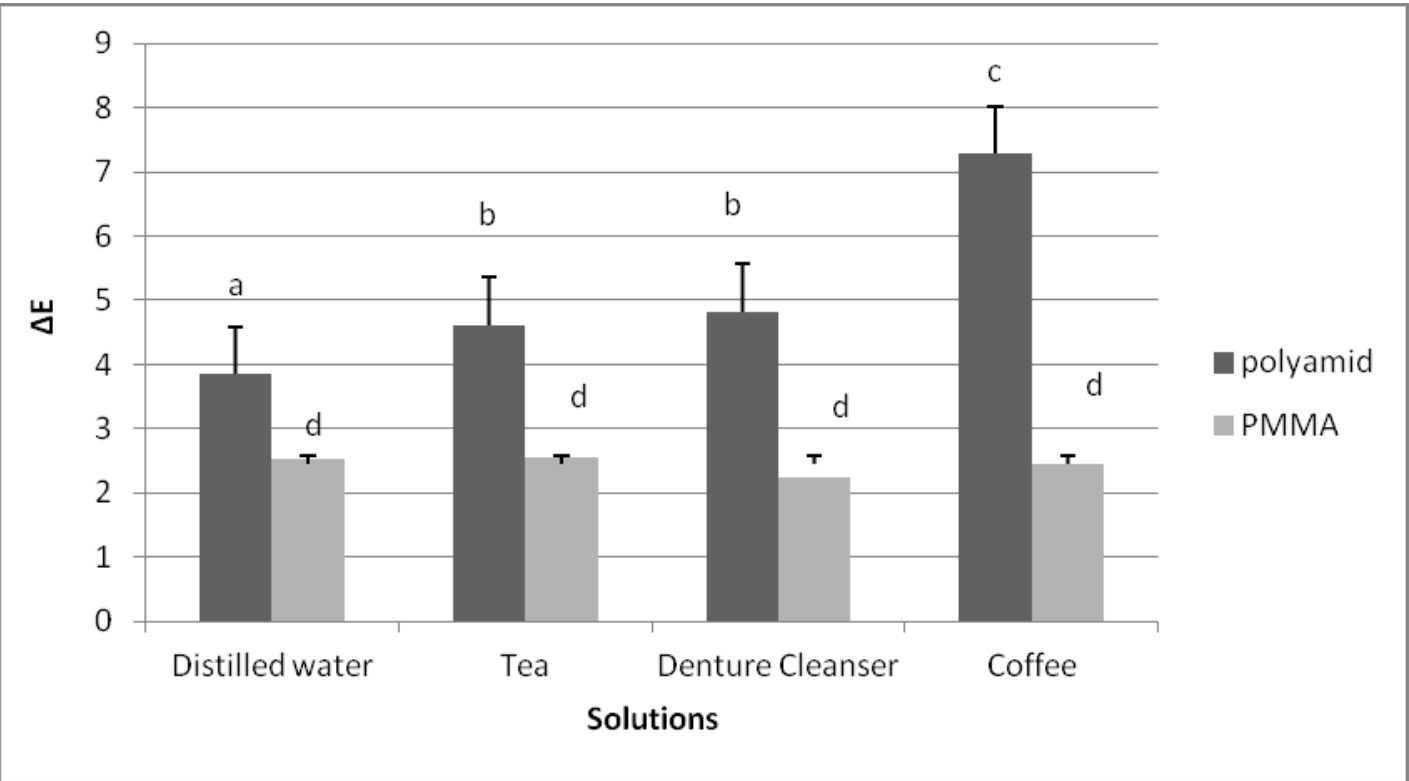

Figure 1. $\Delta \mathrm{E}$ values of specimens in stored different solutions for 7 days (analyzed by Tukey honestly significant difference (HSD) multiple comparison tests). Identical letters indicate that the values are not statistically significant difference $(\mathrm{P}>0.05)$.

polyamid material $(\mathrm{P}<0.001)$.

The polyamid materials also contain auxochromes which, in combination with chromophores and free radicals in solution, may result in staining [1].

Buyukyilmaz et al. [19] stated that one light-polymerized, three heat-polymerized, and three autopolymerized denture base polymers were exposed to coffee, tea, water at 50 degrees ${ }^{\circ} \mathrm{C}+/-1$ degree ${ }^{\circ} \mathrm{C}$, as well as artificial 


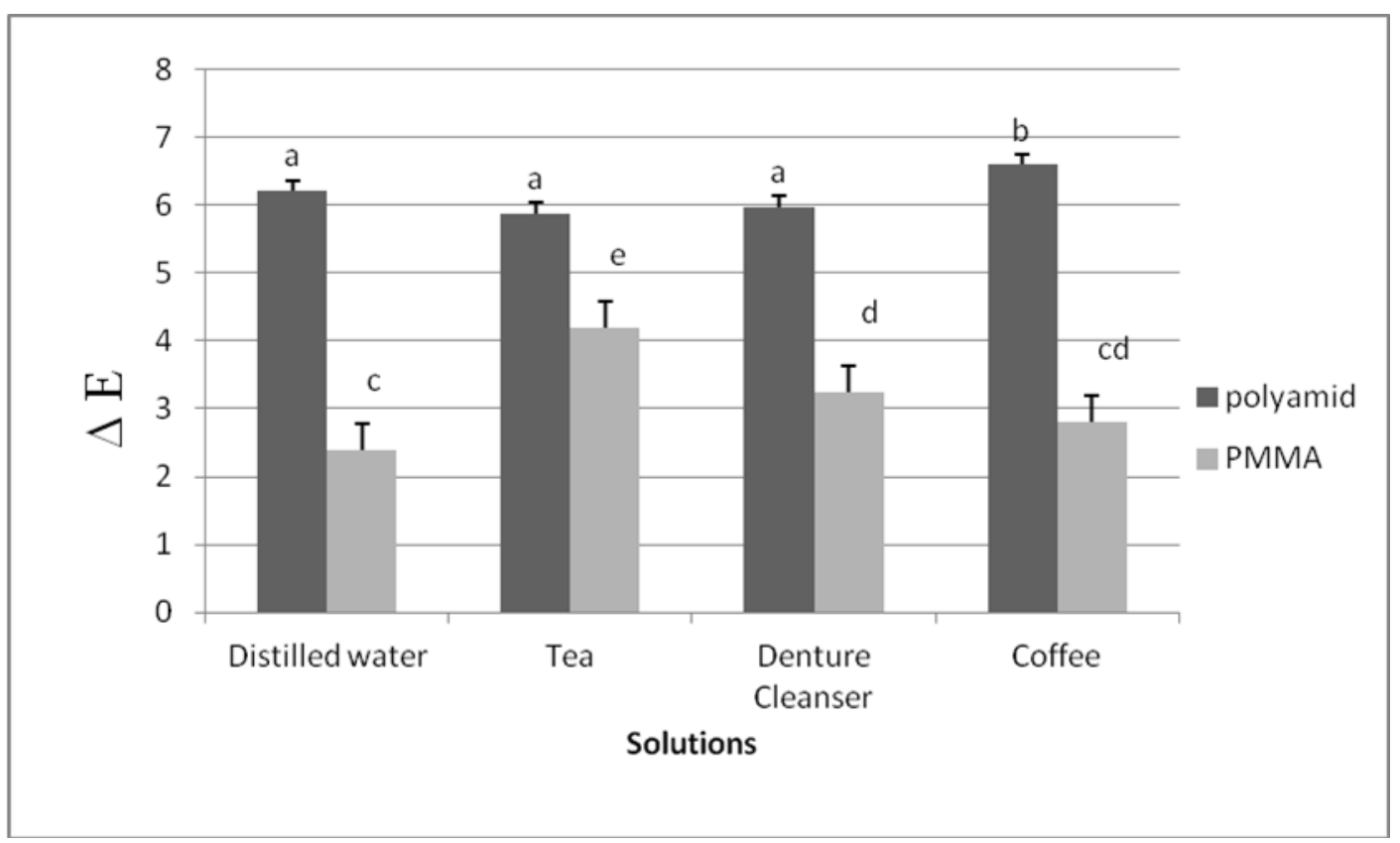

Figure 2. $\Delta \mathrm{E}$ values of specimens in stored different solutions for 30 days (analyzed by Tukey honestly significant difference (HSD) multiple comparison tests). Identical letters indicate that the values are not statistically significant difference $(\mathrm{P}>0.05)$.

sunlight and water, and evaluated for color stability. Coffee and tea stained the denture base materials superficially.

Imirzalioglu et al. [20] showed that the effect of staining solutions on the color of each test material in each session was perceivable by the human eye $(\Delta \mathrm{E}>1)$; however, the color shifts of all test materials were clinically acceptable $(\Delta \mathrm{E}<3.7)$.

The color stability of denture base materials when they were exposed to coffee, tea, mouth wash, Turkish coffee. Turkish coffee solution exhibited more staining capacity than the other solutions [21].

Sepúlveda-Navarro et al. [22] suggested that Chromatic changes were exhibited by specimens immersed in red wine, followed by coffee. For Transflex, cola also promoted color changes. The values of color changes converted to (NBS) National Bureau of Standard units showed them to be perceivable to the human eye.

Aysan et al. [23] evaluated that when kept in different solution taken intraorally, polyamid denture base material was more stained than the polymethylmethacrylate base materials. The color change of denture base materials were increased in tea. This results was same as present study.

In the present study, PMMA was showed the highest $\Delta \mathrm{E}$ value (4.20) in tea while polyamid material that of coffee solution ( $\triangle \mathrm{E}: 7.28)$.

Time was found to be a critical factor for color stability of denture base materials. The immerison time increased color changes become more intensive [16].

Polyamid showed a greater color change compared to PMMA, especially in the coffee solution for 7 days. The color change of polyamid denture base materials was increased with time of storage. Furthermore, color measurements can be affected by surface reflections, inside diffusion and absorption in the specimens and the back ground [1].

In other study, all flange materials tested demonstrated color stability in air and water. However, the color changes of silicone and copolyamide materials stored in coffee solution for 180 days were greater than 3 NBS (National Bureau of Standards) units, which would be characterized as appreciable and considered clinically unacceptable [24]. Staining occurs due to the physical penetration of pigments between the molecular lattices or the adsorption of pigments on the surface of specimens [25].

May et al. [26] evaluated that the color stability of five denture base acrylic resins and one denture base repair resin. The samples were subjected to conditions of accelerated aging to test color stability. It was found the least color-stable of the materials. 
In the study of Giato et al. [27] the thermo-injected flexible resin was presented the greatest chromatic alteration value after accelerated aging.

Peracini et al. [28] suggested that the color changes were significantly higher for the Corega Tabs than for the control group, but the color changes after the immersion in denture cleansers were clinically insignificant. In the present study, denture cleanser was no effected on colour stability of denture base materials.

The color stability of denture base acrylic resins is influenced by denture cleanser [29]. Sato et al. [30] showed that chemical denture cleansers used according to the manufacturers' specifications did not cause color changes in heat-polymerized acrylic resins submitted to soaking cycles that simulated 30 days of use.

The denture cleansing agents exhibited the ability to remove stain from the denture base materials most effectively. Irregularities and porosities present on the denture surface played a major role in reducing the activity of denture cleaning agents and hence increased stain and plaque retention [12].

Bayındır et al. [31] found that methyl methacrylate resin provisional materials were more color stable than autocured bis-acyrl provisional materials. After immersion for all materials showed visible color changes. The coffee solution exhibited more staining than others groups.

In the present study the influence of solutions on the color changes of denture base materials was found similar. The greatest color change was observed in polyamide \& coffee combinations, the lowest color change was observed in PMMA \& Denture cleanser combinations. And the colour stability of polymetyhl methacrylate denture base resin is greater than polyamid denture base resin. The color stability of polyamids should be made better. Clinically patients that use prothesis were made polyamid denture base materias should be warned about cleaning of the prothesis.

\section{Conclusions}

With in the limitation of this study;

1) There were no statistically significant differences between solutions on the colour changes of denture base materials $(\mathrm{P}>0.05)$.

2) Polyamid material showed the greatest colour change when compared to PMMA material $(\mathrm{P}<0.001)$.

3) The highest color change was observed in polyamide \& coffee combinations $(\Delta \mathrm{E}=7.29)$.

4) The lowest color change was observed in PMMA \& denture cleanser combinations $(\Delta E=2.25)$.

\section{Conflict of Interests}

The authors declare that there is no Conflict of Interests regarding the publication of this paper.

\section{Acknowledgements}

This research was supported financially by the Department of Scientific Research Projects of Ataturk University (Project No. 2003/158) and (Project no. 2010/141).

This study was presented at FDI 2013 Istanbul 101 ${ }^{\text {st }}$ Annual World Dental Congress in Turkey, August 28-31, 2013.

\section{References}

[1] Takabayashi, Y. (2010) Characteristic of Denture Thermoplastic Resins for Non-Metal Clasp Dentures. Dental Material Journal, 29, 352-361. http://dx.doi.org/10.4012/dmj.2009-114

[2] Rickman, L.J., Padipatvuthikul, P. and Satterthwaite, J.D. (2012) Contemporary Denture Base Resins: Part 2. Dental Update, 39, 176-178, 180-182, 184.

[3] Yunus, N., Rashid, A.A., Azmi, L.L. and Abu-Hassan, M.I. (2005) Some Flexural Properties of a Nylon Denture Base Polymer. Journal of Oral Rehabilitation, 32, 65-71. http://dx.doi.org/10.1111/j.1365-2842.2004.01370.X

[4] Kuwahara, K., Nagahama, F., Kitahara, K., Wada, M., Makimura, M., Kimura, K., Sakamaki, H., Indou, J., Ogura, K. and Kobayashi, K. (2004) A Case of Using Non-Metal Clasp Partial Denture for the Patient with the Metal Allergy. Nihon University Journal of oral Science, 30, 134-139.

[5] Ideiaslab—Prótese Flexível PPFlex. [Internet]. Rio de Janeiro [cited 2009 Apr 15]. http://www.ideiaslab.com.br

[6] Valplast International Corporation. [Internet]. [cited 2009 Apr 15]. http://www.valplast.com

[7] John, J., Gangadhar, S.A. and Shah, I. (2001) Flexural Strength of Heat-Polymerized Polymethyl Methacrylate Denture 
Resin Reinforced with Glass, Aramid, or Nylon Fibers. Journal of Prosthetic Dentistry, 86, 424-427. http://dx.doi.org/10.1067/mpr.2001.118564

[8] Purnaveja, S., Fletcher, A.M., Ritchie, G.M., Amin, W.M., Moradians, S. and Dodd, A.W. (1982) Colour Stability of Two Self Curing Denture Base Materials. Biomaterials, 3, 249-250. http://dx.doi.org/10.1016/0142-9612(82)90029-1

[9] May, K.B., Shotwell, J.R., Koran, A. and Wang, R.F. (1996) Color Stability: Denture Base Resins Processed with the Microwave Method. Journal of Prosthetic Dentistry, 76, 581-589. http://dx.doi.org/10.1016/S0022-3913(96)90433-3

[10] Scotti, R., Mascellani, S.C. and Forniti, F. (1997) The in Vitro Color Stability of Acrylic Resins for Provisional Restorations. The International Journal of Prosthodontics, 10, 164-168.

[11] Jagger, D.C., Al-Akhazam, L., Harrison, A. and Rees, J.S. (2002) The Effectiveness of Seven Denture Cleansers on Tea Stain Removal from PMMA Acrylic Resin. International Journal of Prosthodontics, 15, 549-552.

[12] Shotwell, J.L., Razzoog, M.E. and Koran, A. (1992) Color Stability of Long-Term Soft Denture Liners. Journal of Prosthetic Dentistry, 68, 836-838. http://dx.doi.org/10.1016/0022-3913(92)90213-T

[13] Rosentritt, M., Esch, J., Behr, M., Leibrock, A. and Handel, G. (1998) In Vivo Color Stability of Resin Composite Veneers and Acrylic Resin Teeth in Removable Partial Dentures. Quintessence International, 29, 517-22.

[14] Berns, R.S. (2000) Billmeyer and Saltzman’s Principles of Color Technology. 3rd Edition, Wiley, New York, 71-74.

[15] Wu, J.C., Latta, G.H., Wicks, R.A., Swords, R.L. and Scarbecz, M. (2003) In Vitro Deformation of Acetyl Resin and Metal Alloy Removable Partial Denture Direct Retainers. Journal of Prosthetic Dentistry, 90, 586-590. http://dx.doi.org/10.1016/j.prosdent.2003.09.020

[16] Abu-Bakr, N., Han, L., Okamoto, A. and Iwaku, M. (2000) Color Stability of Compomer after Immersion in Various Media. Journal of Esthetic Dentistry, 12, 258-263. http://dx.doi.org/10.1111/j.1708-8240.2000.tb00232.x

[17] Wilson, N.H., Burke, F.J. and Mjör, I.A. (1997) Reasons for Placement and Replacement of Restorations of Direct Restorative Materials by a Selected Group of Practitioners in the United Kingdom. Quintessence International, 28, 245248.

[18] Villalta, P., Lu, H., Okte, Z., Garcia-Godoy, F. and Powers, J.M. (2006) Effects of Staining and Bleaching on Color Change of Dental Composite Resins. Journal of Prosthetic Dentistry, 95, 137-142. http://dx.doi.org/10.1016/j.prosdent.2005.11.019

[19] Buyukyilmaz, S. and Ruyter, I.E. (1994) Color Stability of Denture Base Polymers. International Journal of Prosthodontics, 7, 372-382.

[20] Imirzalioglu, P., Karacaer, O., Yilmaz, B. and Ozmen, I. (2010) Color Stability of Denture Acrylic Resins and a Soft Lining Material against Tea, Coffee, and Nicotine. Journal of Prosthodontics, 19, 118-124. http://dx.doi.org/10.1111/j.1532-849X.2009.00535.x

[21] Duymus, Z.Y., Yanıkoglu, N. and Arık, M. (2010) Evaluation of Colour Changed of Acrylic Resin Materials in the Different Solutions. Asian Journal of Chemistry, 22, 6669-6676.

[22] Sepúlveda-Navarro, W.F., Arana-Correa, B.E., Borges, C.P.F., Jorge, J.H., Urban, V.M. and Campanha, N.H. (2011) Color Stability of Resins and Nylon as Denture Base Material in Beverages. Journal of Prosthodontics, 20, 632-638. http://dx.doi.org/10.1111/j.1532-849X.2011.00791.X

[23] Aysan, I., Uçar, Y. and Üşümez, A. (2011) Üç farklı kaide materyalinin farklı solüsyonlardaki renk stabilitesinin karş1laştırılması [A Comparison of the Color Stability of Three Different Base Materials in the Different Solutions]. The Journal of Dental Faculty of Atatürk University, 21, 219-225.

[24] Lai, Y.L., Lui, H.F. and Lee, S.Y. (2003) In Vitro Color Stability, Stain Resistance, and Water Sorption of Four Removable Gingival Flange Materials. Journal of Prosthetic Dentistry, 90, 293-300. http://dx.doi.org/10.1016/S0022-3913(03)00432-3

[25] Ueda, K., Takeda, T., Ichiwata, T., Kabayashi, Z., Nakamura, T., Marita, E., Gotoh, H., Umi, T., Satoh, Y. and Ohki, K. (1985) Studies on the Coloration of Denture Base Part I. On the Influence of Surface Roughness and Favorite Taste. The Journal of the Japan Prosthodontic Society, 29, 85-93. http://dx.doi.org/10.1016/0022-3913(92)90290-Q

[26] May, K.B., Razzoog, M.E., Koran, A. and Robinson, E. (1992) Denture Base Resins: Comparison Study of Color Stability. Journal of Prosthetic Dentistry, 68, 78-82. http://dx.doi.org/10.1016/0022-3913(92)90290-Q

[27] Goiato, M.C., Santos, D.M., Haddad, M.F. and Pesqueira, A.A. (2010) Effect of Accelerated Aging on the Microhardness and Color Stability of Flexible Resins for Dentures. Brazilian Oral Research, 24, 114-119.

[28] Peracini, A., Davi, L.R., Ribeiro, N., de Souza, R.F., da Silva, C.H.L. and Paranhos, H. (2010) Effect of Denture Cleansers on Physical Properties of Heat-Polymerized Acrylic Resin. Journal of Prosthodontic Research, 54, 78-83. http://dx.doi.org/10.1016/j.jpor.2009.11.004

[29] Hong, G., Murata, H., Li, Y., Sadamori, S. and Hamada, T. (2009) Influence of Denture Cleansers on the Color Stability of Three Types of Denture Base Acrylic Resin. Journal of Prosthetic Dentistry, 101, 205-213. 
http://dx.doi.org/10.1016/S0022-3913(09)60032-9

[30] Sato, S., Cavalcante, M.R., Orsi, I.A., Hde, F.P. and Zaniquelli, O. (2005) Assessment of Flexural Strength and Color Alteration of Heat-Polymerized Acrylic Resins after Simulated Use of Denture Cleansers. Brazilian Dental Journal, 16, 124-128. http://dx.doi.org/10.1590/S0103-64402005000200007

[31] Bayındır, F., Kürklü, D. and Yanıkoğlu, N. (2012) The Effect of Staining Solutions on the Color Stability of Provisional Prosthodontic Materials. Journal of Dentistry, 40, 41-46. http://dx.doi.org/10.1016/j.jdent.2012.07.014 
Scientific Research Publishing (SCIRP) is one of the largest Open Access journal publishers. It is currently publishing more than 200 open access, online, peer-reviewed journals covering a wide range of academic disciplines. SCIRP serves the worldwide academic communities and contributes to the progress and application of science with its publication.

Other selected journals from SCIRP are listed as below. Submit your manuscript to us via either submit@scirp.org or Online Submission Portal.
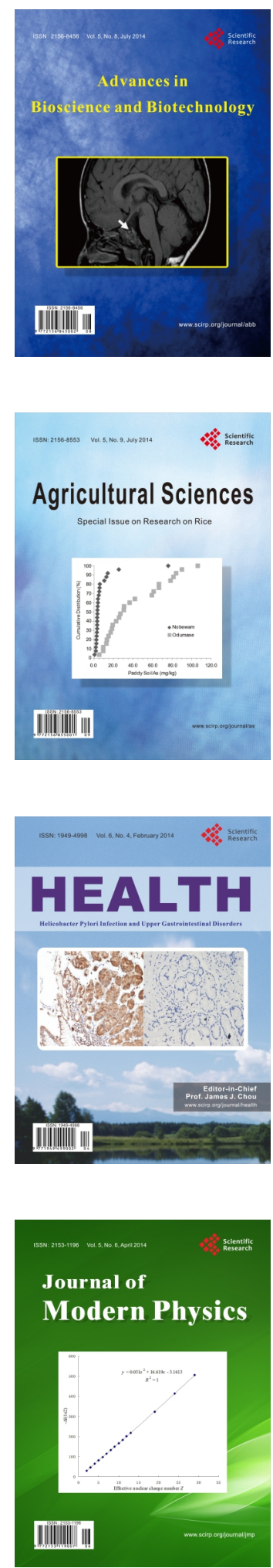
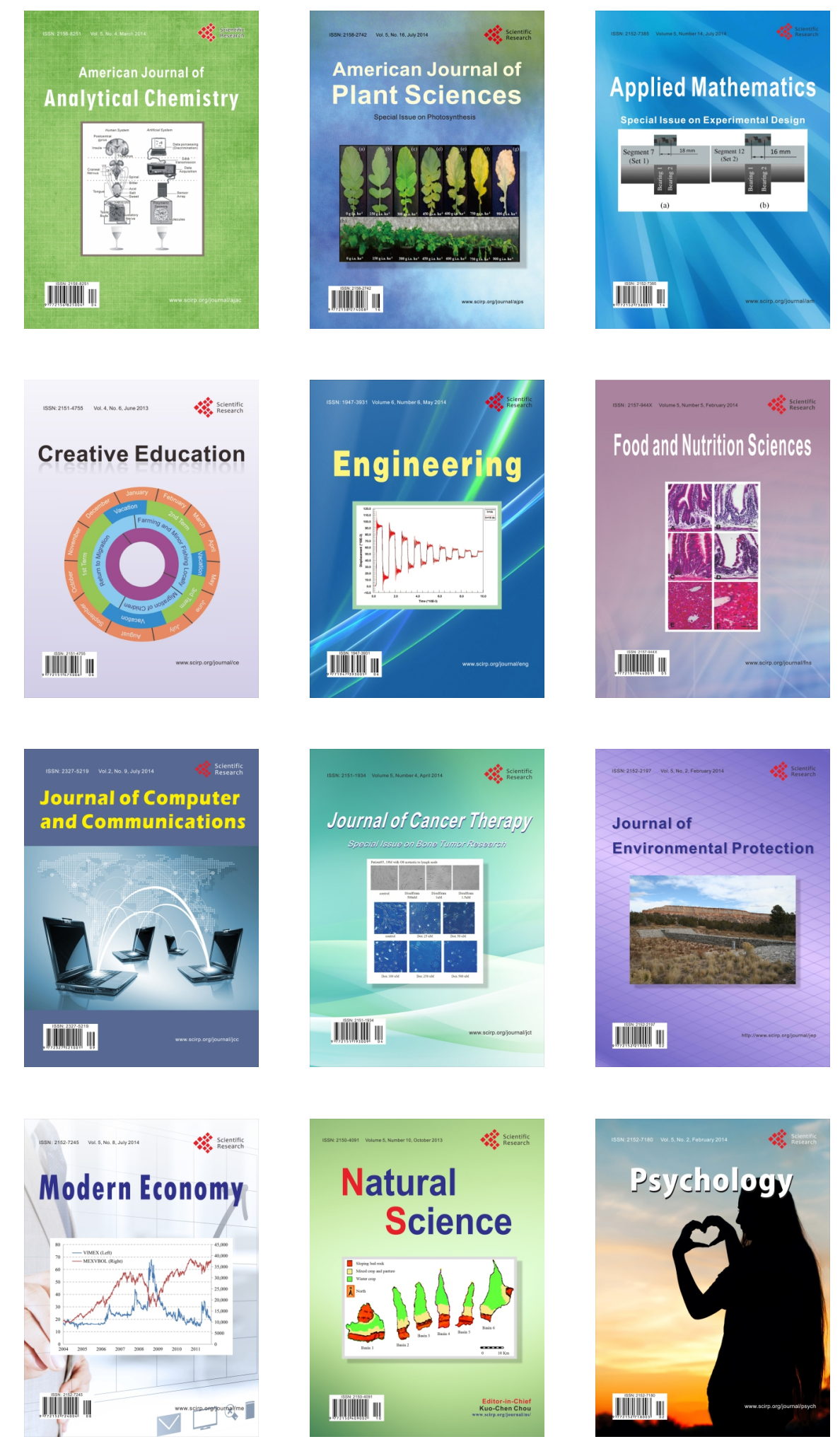